\title{
New Miocene sulid birds from Peru and considerations on their Neogene fossil record in the Eastern Pacific Ocean
}

\author{
Marcelo Stucchi, Rafael M. Varas-Malca, and Mario Urbina-Schmitt \\ Acta Palaeontologica Polonica 61 (2), 2016: 417-427 doi:http://dx.doi.org/10.4202/app.00170.2015
}

Boobies and gannets (family Sulidae) are the most specialized plunge divers among seabirds. Their fossil record along the Pacific coast of South America extends to the early Middle Miocene. Here we describe three new species of sulids: Sula brandi sp. nov., Sula figueroae sp. nov., and Ramphastosula aguirrei sp. nov., from the early Late Miocene of the Pisco Formation (Peru). Two of them are relatives of the living genus Sula, which represents medium and large-sized boobies. A new species of the extinct genus Ramphastosula is also described, adding to the discussion of possible alternative feeding strategies among sulids. The fossil record suggests that sympatric sulids exhibit different body sizes at least since the Oligocene epoch, a strategy related with resource partitioning. Furthermore, we find current analysis and knowledge of the fossil record unsuitable to evaluate properly seabird diversity changes through time.

Key words: Aves, Pelecaniformes, Sulidae, Sula, Ramphastosula, seabird evolution, Miocene, Peru.

Marcelo Stucchi [aicb.peru@gmail.com], Asociación para la Investigación y Conservación de la Biodiversidad (AICB). Av. Vicús 538 Lima 33, Perú. Rafael

M. Varas-Malca [varas.m.r@gmail.com] (corresponding author) and Mario Urbina-Schmitt [mariourbina01@ hotmail.com], Departamento de Paleontología de Vertebrados. Museo de Historia Natural "Javier Prado". Universidad Nacional Mayor de San Marcos. Av. Arenales 1256, Lima 14, Perú.

This is an open-access article distributed under the terms of the Creative Commons Attribution License (for details please see creativecommons.org), which permits unrestricted use, distribution, and reproduction in any medium, provided the original author and source are credited. 
Farf Full text (697.4 kB) ।

For's Supplementary file $(51.6 \mathrm{kB})$ 